\title{
A New Hydridocarbonyl Gomplex of Osmium(II)
}

By F. G. Moers

(Inorganic Chemistry Laboratory, University of Nijmegen, Nijmegen, The Netherlands)

Reprinted from

\section{Chemical Communications 1971}

The Chemical Society, Burlington House, London WIV OBN 


\title{
A New Hydridocarbonyl Complex of Usmium(II)
}

\author{
By F. G. Moers \\ (Inorganic Chemistry Laboratory, University of Nijmegen, Nijmegen, The Netherlands)
}

Summary The reaction of $\mathrm{K}_{2} \mathrm{OSCl}_{6}$ with tricyclohexylphosphine in alcohols leads to the hydridocarbonyl complex $\mathrm{OsHCl}(\mathrm{CO})\left(\mathrm{PCy}_{3}\right)_{2}$.

Гнғ: hydridecarbonylphosphine complexes with the formula $\mathrm{MIHX}(\mathrm{CO})\left(\mathrm{PI}_{3}\right)_{3}$ where $\mathrm{II}=\mathrm{Ru}$ or $\mathrm{Os}$ and $\mathrm{X}=\mathrm{Cl}$ or $\mathrm{Br}$ may be obtained directly from the metal halides, triphenylphosphine, and alcohols. ${ }^{1}$ Stephenson and Wilkinson" (lescribe the preparation of the complex $\mathrm{RuCl}_{2}\left(\mathrm{PPh}_{3}\right)_{3}$ by refluxing a methanolic solution of $\mathrm{I}^{\prime} \mathrm{Ph}_{3}$ and $\mathrm{RuCl}_{3}$ under nitrogen.

I now report the isolation of the complex OsHCl(CO)$\left(\mathrm{P}^{\prime} \mathrm{C}_{3}\right)_{2} \quad\left(\mathrm{PC}_{3}=\right.$ tricyclohexylphosphine). On boiling a solution of $\mathrm{PC}_{3}$ and $\mathrm{K}_{2} \mathrm{OsCl}_{6}$ in 2-methoxyethanol in an atmosphere of nitrogen for $48 \mathrm{~h}$, a red complex. OsHCl(CO)$\left(\mathrm{I}^{\prime} \mathrm{C} \mathrm{y}_{3}\right)_{2}$, was obtained. The complex had satisfactory analytical data.

The complex decomposes at $210^{\circ}$ and is slightly soluble in organic solvents. It is diamagnetic (measured between rom temperature and $\left.-151^{2}\right)$ indicating a low spin $d^{6}$ configuration.

The i.r. spectrum ( $\mathrm{K} / \mathrm{Br}$ ) in the range $2100-1850 \mathrm{~cm}^{-1}$ shows two bands attributable $t o$ y $(\mathrm{CO})$ stretching modes at 19:32: and $1887 \mathrm{~m} \mathrm{~cm}^{-1}$ and one band at $2012 \mathrm{~cm}^{-1}$ assigned to $v(M-H)$. On performing the reaction in deuteriated ethand. the expected frequency shift for a covalent osmiumhydrogen band was found $v(M-I)$ ) at $1508 w \mathrm{~cm}^{-1}$, the other two bands being unchanged. The split nature of the carbonyl bands, which is maintained in benzene solution. suggests that the complex is a mixture of geometrical isomers. So far, attempts to separate isomers have not

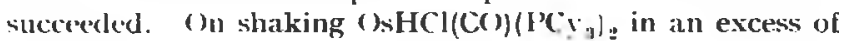

pyridine a yellow complex, $\mathrm{OsHCl}(\mathrm{CO})\left(\mathrm{PCy}_{3}\right)_{2} \mathrm{Py}$, was obtained. The pyridine complex shows two i.r. absorption bands $(\mathrm{KBr})$ at $2119 \mathrm{~m}$ and $1870 \mathrm{~s} \mathrm{~cm}^{-1}$ attributable to $v(\mathrm{CO})$ and one weak band at $2040 \mathrm{~cm}^{-1}$ assigned to $v(\mathrm{M}-\mathrm{H})$.

In the mass spectrum there is a cluster, with the lowest fragment ion having $m / e \mathbf{8 0 8}$ which is in agreement with the formula ${ }^{184} \mathrm{OsH}^{35} \mathrm{Cl}(\mathrm{CO})\left(\mathrm{PCy}_{8}\right)_{2}$. The relative abundances of the peaks in this cluster agree with the calculated ratios. Fragment ions with higher masses than OsHCl(CO) $\left(\mathrm{PCy}_{3}\right)_{2}$ could not be detected. Comparison of the mass spectra of $\mathrm{OsHCl}(\mathrm{CO})\left(\mathrm{PCy}_{3}\right)_{2}$ and its deuteriated derivative, prepared as described above, showed appreciable deuteriation of $\mathrm{PCy}_{3}$ indicated by the presence of peaks at $m / e 280-290$. As a result we found that the ratios of the cluster of peaks due to $\mathrm{OsDCl}(\mathrm{CO})\left(\mathrm{PC}_{3}\right)_{2}$ differed. from the calculated $\mathrm{OsDCl}(\mathrm{CO})\left(\mathrm{PCy}_{3}\right)_{2}$ ratios in which the $\mathrm{PCy}_{3}$ is non-deuteriated. These data suggest an exchange reaction between the complex and deuterium during the preparation of the complex.

All attempts to prepare $\mathrm{OsHCl}(\mathrm{CO})\left(\mathrm{PCy}_{3}\right)_{3}$ by addition of an excess of $\mathrm{PCy}_{3}$ were unsuccessful. The fact that this complex could not be isolated may be due to the steric hindrance of the cyclohexyl groups. ${ }^{3}$

The structure of this complex is probably related to that of the complexes $\mathrm{RuHX}\left(\mathrm{PPh}_{3}\right)_{3},{ }^{4}$ the diamagnetic complex $\mathrm{RuX}_{2}\left(\mathrm{SbPh}_{3}\right)_{3},{ }^{2}$ and $\mathrm{RuCl}_{2}\left(\mathrm{PPh}_{3}\right)_{3}$. An $X$-ray study by La Placa and Ibers ${ }^{5}$ has shown a quasi-octahedral structure for $\mathrm{RuCl}_{2}\left(\mathrm{PPh}_{3}\right)_{3}$.

I thank Prof. Dr. Ir. J. J. Steggerda for discussions, Mr. J. P. Langhout for helpful assistance, and Dr. F. Gerhartl for recording the mass spectra.

(Received, Noiember 18th, 1970; Com. 1994.)

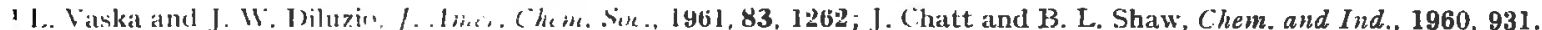

T. A. Stephenson and (i. Wilkinson. J. Inorg. Nuclear Chem., 1966, 28, 945.

3 I. S. Green and K. Saito. Chem. Comm., 1969. 20x; F. G. Moers and P. H. op het Veld, J. Inorg. . Vuclear Chem., 1970, $32,3225$.

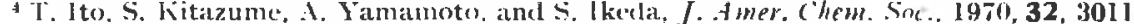

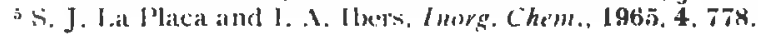

